\title{
Headache Frequency among the Health Care Workers and the Relationship
}

\section{Working Conditions}

Sağlık Çalışanlarında Baş ağrısı Sıklığı ve Çalışma Şartları ile ilişkisi

Süber Dikici ${ }^{1}$, Davut Baltacı ${ }^{2}$, Güven Arslan ${ }^{1}$, Gülşen Atar $^{3}$, Nurten Ercan ${ }^{1}$, Aylin Yılmaz $^{2}$, Ahmet Çeler ${ }^{2}$, İsmail Hamdi Kara ${ }^{2}$

${ }^{1}$ Düzce Üniversitesi Tıp Fakültesi Nöroloji Ana Bilim Dalı, Düzce

${ }^{2}$ Düzce Üniversitesi Aile Hekimliği Ana Bilim Dalı, Düzce

${ }^{3}$ Düzce Üniversitesi Tıp Fakültesi Sosyal Hizmetler Uzmanı

\section{Özet}

Amaç: Bu çalışma Düzce Üniversitesi Tıp Fakültesi sağlık çalışanlarında başağrısı sıklığını, başağrısının karakteristiğini, sosyo-demografik özelliklerini, çalışma koşulları ve memnuniyet durumlarının değerlendirilmesi amacıyla yapıldı.

Yöntem: Kesitsel tipteki bu çalışmada olgular, teknisyen ( $n=32, \% 15,9)$, hemşire $(n=100, \% 49,8)$, sözleşmeli personel $(n=29, \% 14,4)$ ve memurlar $(n=40, \% 19,9)$ olarak 4 grupta incelendi. Olgulara sosyodemografik faktörler ve baş ağrısının özelliklerine ilişkin bir anket yüz yüze görüşme yöntemiyle uygulandı. Başağrısının tanısı için Uluslararası Başağrısı Topluluğunun kriterleri kullanıldı.

Bulgular: Çalışma, yaş ortalaması $30.3 \pm 6.8$ (20-56) yıl olan, 57'si $(\% 28,4)$ erkek, 144'ü $(\% 71,6)$ kadın olan, toplam 201 olguda gerçekleştirildi. Olguların çoğu üniversite mezunuydu ( $n=122, \% 60,7 ; p<0.0001)$. Evli olgular $(130, \% 64,7)$ çoğunluktaydı. Olguların çoğu 10 yıl ve daha az çalışma süresine $(154, \% 76,6)$ sahipti. Olgularda başağrısı görülme sıklı̆̆ı; teknisyenlerde $\% 50$, hemşirelerde $\% 58$, sözleşmeli personellerde $\% 37,9$ ve memurlarda $\% 62,5$ idi $(p<0.05)$. En yüksek MiDAS skoru ortalaması teknisyenlerde $(7.8 \pm 4.9)$ iken, en düşük skor hemşirelerdeydi $(5.9 \pm 4.7),(p<0.0001)$. Baş ağrısı ile kadın cinsiyeti arasında $r=0,228, p=0.001$ pozitif korelasyon saptandı. Çalışma koşullarından memnuniyetin en az olduğu grup teknisyenlerdi.

Sonuç: MiDAS skoru ve başağrısı süresi en fazla teknisyenlerde gözlendi. Çalışma memnuniyetin en az olduğu grup da yine teknisyenlerdi. Çalışanların çoğu doktor tavsiyesi olmadan ağrı kesici alıyordu. Özellikle ağrı kesici kullanımı hakkında hasta eğitimi tüm sağlık birimlerinde verilmelidir.

Anahtar Kelimeler: Demir eksikliği anemisi, tiroid hormonlari.

\section{Introduction}

International Association for the Study of Pain (IASP) defines pain as sensually or emotionally unpleasant feeling emerging from somewhere of the body, accompanied with real or possible tissue damage and concerned with patient's past experiments $(1,2)$. Pain is composed of 3 parts; feeling the pain (sensory part), perception (cog

\begin{abstract}
Objective: This study was evaluated that frequency of headache, headache characteristics, socio-demographic characteristics, working conditions and the status of satisfaction between health care workers in Duzce University School of Medicine.
\end{abstract}

Method: This cross sectional study was analyzed in four groups of cases as follows technicians ( $n=32,15.9 \%)$, nurses ( $n=100,49.8 \%)$, contracted personnel $(n=29,14.4 \%)$ and officials ( $n=40,19.9 \%$ ). A questionnaire on sociodemographic characteristics and headache were interviewed face to face. International Headache Society criteria were used for the diagnosis of headache.

Results: The study was carried out in total of 201 cases whose average age is about $30.3 \pm 6.8$ years $(20-56)$, male $28.4 \%(n=57)$ and female $71.6 \%(n=144)$. Most of the cases were university graduate $60.7 \%(n=122),(p<0.0001)$. Majority of personal had 10 years of working or less. The incidences of headache in cases were as follows; in technicians: $50 \%$, in nurses $\% 58$, in contracted personnel $37.9 \%$ and in officials' $62.5 \%(p<0.05)$. The greatest MIDAS score average was in technicians $7.8 \pm 4.9$ yet the lowest score was in nurses $5.9 \pm 4.7,(p<0.0001)$. A positive correlation was found between headache and female gender. The lowest rate of pleasure of working conditions was found in the technician group.

Conclusion: The study indicated that MIDAS score, heights headache duration was observed among technicians. This situation is possibly concerned with the technicians being the lowest rated group in working conditions pleasure questionnaire. It was concluded that most of the cases used painkillers without taking doctors' advice. The patient education should be given all the health units about use of painkillers.

Keywords: Headache, pain killers, MIDAS score. nitive part) and repsonse to pain (affective part). Gross feeling of pain takes place in hypothalamus and complete perception of pain takes place in parietal cortex. When sensed, pain causes voluntary or involuntary motor responses both of which are protective in manner (3). 
Majority of the headaches are chronic pains like migraine and tension type headache.These kind of headaches may affect the patient directly with their characteristic features or indirectly with the results of the pain.On the other hand, depression and some other psychiatric events may cause these kind of headaches or make them frequent. Epidemiologic studies devoted to headaches improves our understanding of prevelance and dispersion of headaches and relations of age,gender,race and socioeconomic conditions with the pain. So understanding mechanisms of pain and improving treatment options are possible (4).

Previous epidemiological studies of headaches in adults mostly focused on migraine.Migraine in adults is a disease which has high prevelance and social effects. It is stated that migraine is the most common headache in primary headaches and it causes absenteeism and incapability in daily activities.The prevelance in community varies depending on the defining criterias (5). Migrain is a high incident and prevelant disesase which reduce the quality of life and work power. It is an important burden for the community.Therefore, preventive medicine and treatment becomes prominent $(6,7)$. The burden of only migraine to USA budget is estimated to be 1.4-17.2 billion dollars yearly. Another study in England revealed that work power loss due to migraine was 5.6 days ( 1.5 days not going to work at all, 4.1 days of reduced efficency) in males and 6.7,2.1 and 4.6 days in females respectively (6). So it is needed to know the profile of the community and the variables well. In Turkey, several studies showed clinical features of headache cases and sociodemographic profiles of them $(8,9,10)$. Headache criterias were decided by the International Headache Society (HIS) Classification Comitee in 1988. So the variabilities in studies depending on different diagnostic criterias on headache prevelance disappeared and the results of different studies become similar. The questionnaires in most population based studies were carried out by calls or posts. Face to face prevelance studies at door are very rare (11).

The aim of this face to face study is to reveal the headache prevelance and properties in Duzce University Medical Faculty employee and to figu- re out sociodemographic profiles,working conditions and pleasure statuses of cases.

\section{Material and Method}

This cross sectional study was carried out on Duzce University Medical Faculty technic, office and cleaning employee. Totally 201 out of 236 employee included in this study (90\%). Two medical doctor from Duzce University Medical Faculty and a social service supervisor was administered this questionnaire face to face. In this questionnaire, as well as demographic features, headache duration, frequency, format, location, time, characteristics, accompanying symptoms, methods applied in dealing with headache cases, medication use were recorded. The MIDAS (Migraine Disability Assessment) was administered. Evaluation of headaches was done according to the diagnostic criterias of International Headache Society criterias for headaches (2).

SPSS (Statistical Package for Social Sciences) 11.5 PC programme was used in statistical analysis. Comparison of multiplex groups was carried out with One Way ANOVA (Bonferroni) test, on the other hand comparison of two distinct groups was carried out with student $t$ test.Chi-square test (and/or Fisher's exact test) was used in analysis of categorical variables. The results were revealed as mean \pm SD. $p<0.05$ value was interpreted as statistically meaningful.

\section{Results}

The study was carried out on 201 cases of which $57(28.4 \%)$ were male,144 (71.6\%) were female and the average age was $30.3 \pm 6.8$ (2056) years. Most of the cases were university graduate (122 cases, 60.7\%; $p<0.0001$ ). Married cases were in majority $(130,64.7 \%)$. Most of the cases had 10 years or less working time $(154,76.6 \%)$. Cases were technicians $(n=32$, $15.9 \%)$, nurses $(n=100,49.8 \%)$, contracted personnel $(n=29,14.4 \%)$ and officials $(n=40$, $19.9 \%)$. Headache prevelance in our study was 110 cases, \%54.7 and female/male ratio was $89 / 21=4,2$ having a female predominance. Headache prevelance respectively in cases were; technicians: $50 \%$, nurses $58 \%$, contract 
ed personnel $37.9 \%$ and officials $62.5 \%$ idi $(p<0.05)$. The lowest rate of pleasure of working conditions belonged to the technicians' group (59.4\%) (Table 1 ).

Table 1. Headache prevelance and sociodemographic features in cases as occupational groups.

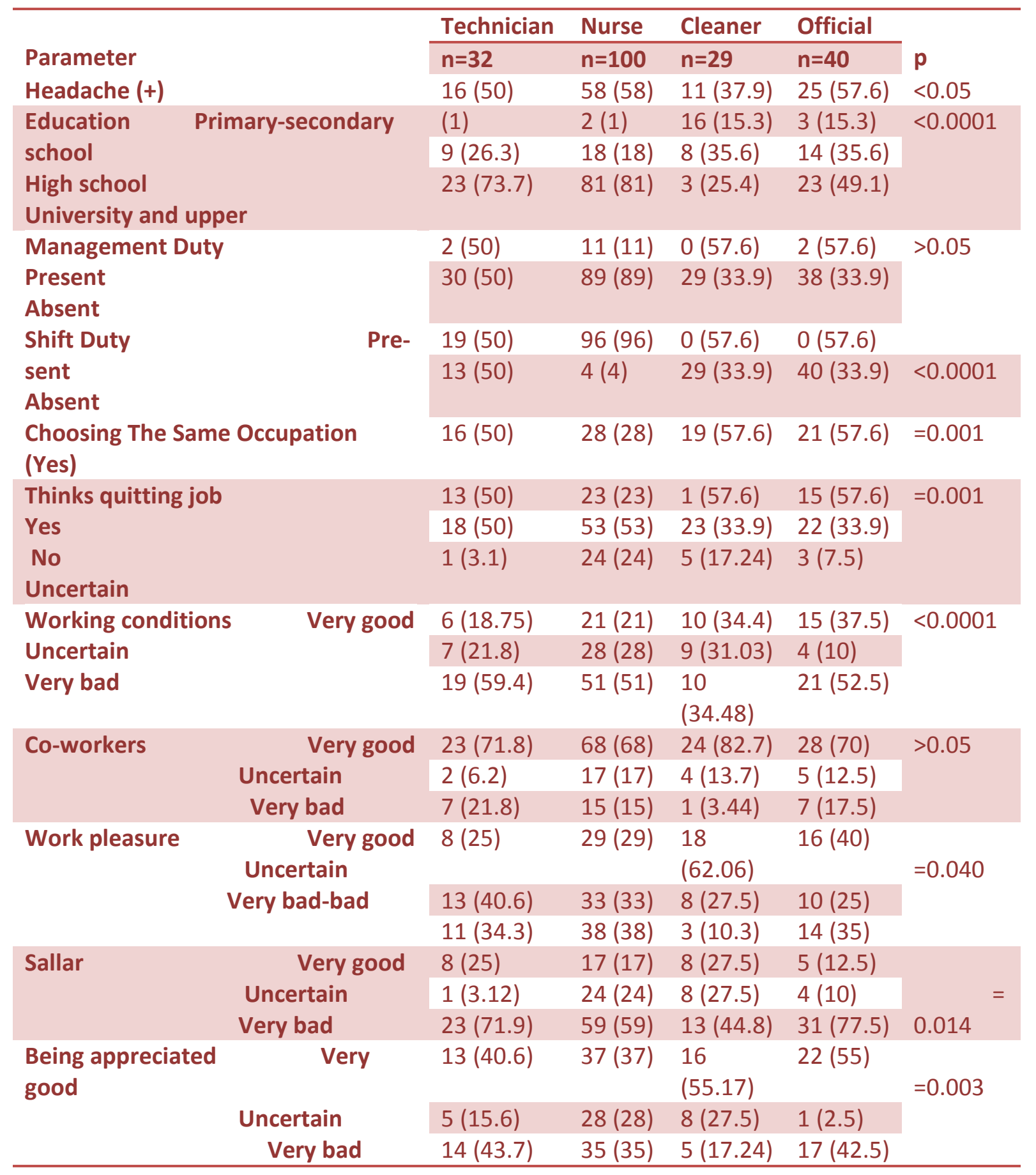


The average onset ages and headache durations (days) in cases were as follows; in technicians: $16.7 \pm 11.6$ years and $15.6 \pm 21.2$ days; in nurses $17.9 \pm 10.1$ years and $9.0 \pm 10.7$ days; in contracted personnel $23.7 \pm 13.8$ years and $6.5 \pm 12.5$ days and in officials $20.1 \pm 13.1$ years $4.4 \pm 9.6$ days ( $p=0.001$ ve $p=0.005)$. The highest MIDAS score average was in technician group $(7.8 \pm 4.9)$ whereas the lowest score belonged to the nurses $(5.9 \pm 4.7),(p<0.0001)$ (Table 2$)$.
On figure 1, analyzing the methods that used by the cases against headaches it is understood that majority in all groups used medicines (51, 46.4\%), and less used multiple methods (33, 30.0\%). Taking medicine was the starting course in officials $(15,60.0 \%)$, in personnel $(6$, $45.6 \%)$ and in nurses $(26,44.8 \%)(p=0.003)$.

Table 2. Headaches and sociodemographic features of occupational groups.

\begin{tabular}{|c|c|c|c|c|c|}
\hline & Technician & Nurse & Cleaner & Official & \\
\hline Parametre & $n=32$ & $n=100$ & $n=29$ & $n=40$ & p \\
\hline Age (Years) & $30.5 \pm 5.3$ & $28.3 \pm 5.0$ & $34.9 \pm 8.0$ & $31.7 \pm 8.9$ & $>0.05$ \\
\hline Total Working Years & $7.8 \pm 4.9$ & $5.9 \pm 4.7$ & $6.6 \pm 4.5$ & $7.0 \pm 7.1$ & $>0.05$ \\
\hline DUMF Hospital Working Years & $5.5 \pm 4.3$ & $3.9 \pm 4.2$ & $5.3 \pm 4.2$ & $4.7 \pm 4.8$ & $>0.05$ \\
\hline Sallary $(\mathrm{TL})^{*}$ & $1657 \pm 307$ & $1676 \pm 323$ & $1200 \pm 200$ & $1388 \pm 380$ & $=0.004$ \\
\hline Onset age of headache & $16.7 \pm 11.6$ & $17.9 \pm 10.1$ & $23.7 \pm 13.8$ & $20.1 \pm 13.1$ & $=0.001$ \\
\hline MIDAS score & $7.8 \pm 4.9$ & $5.9 \pm 4.7$ & $6.6 \pm 4.5$ & $7.0 \pm 7.1$ & $<0.0001$ \\
\hline Headache duration (Sum of days) & $15.6 \pm 21.2$ & $9.0 \pm 10.7$ & $6.5 \pm 12.5$ & $4.4 \pm 9.6$ & $=0.005$ \\
\hline $\begin{array}{l}\text { Headache in previous } 3 \text { months } \\
\text { (Days) }\end{array}$ & $3.4 \pm 2.7$ & $3.6 \pm 2.4$ & $2.3 \pm 2.2$ & $3.7 \pm 2.9$ & $=0.250$ \\
\hline
\end{tabular}

*TL: Turkish Liras

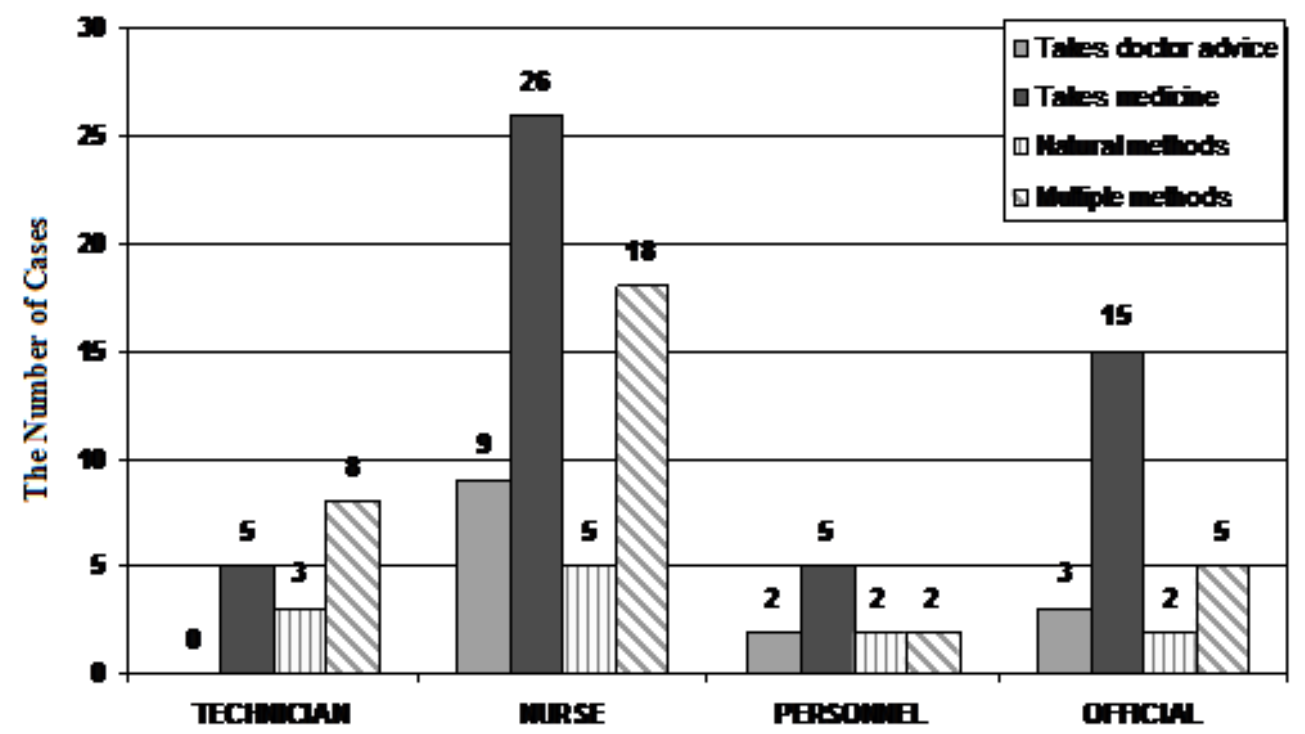

Figure 1. Methods that cases used against headaches. 
110 cases of headache complained of sound intolerance (85 cases, $77.3 \%$ ), pain with physical exercise (55 cases, 50.0\%) and light intolerance ( 53 cases, $48.2 \%$ ) (Figure 2 ).

When all cases are taken into consideration ( $n=201)$, relation of MIDAS score to onset age of headache is $r=0.200, p=0.036$ and relation of MIDAS score to education $r=0.208, p=0.028$ ,positive correlations are found. Again, headache complaint and female gender has positive correlation with each other $r=0.228$, $p=0.001$. When 110 cases of headache evalua- ted a meaningful positive linear correlation between working conditions and pleasure from working contdions is found only in the technician group (Figure 3) (R2=0.61, $\mathrm{p}<0.0001)$. Positive correlations were found between pleasure of work and being appreciated $(r=0.61, p<0.0001)$; pleasure of work and sallary $(r=0.32, p=0.001)$ and work mates $(r=0.26, p=0.006)$; working conditions and sallary $(r=0.39, p<0.0001)$; pleasure of work $(r=0.42, p<0.0001)$ and being appreciated $(r=0.47, p<0.0001)$.

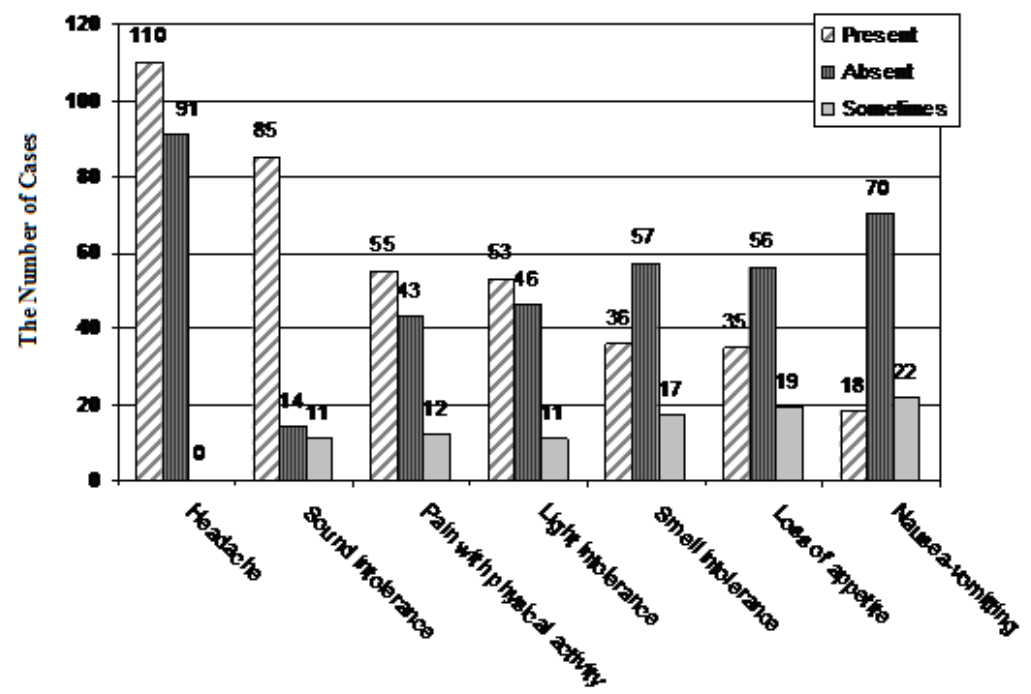

Figure 2. Symtoms and signs accompanying headaches.

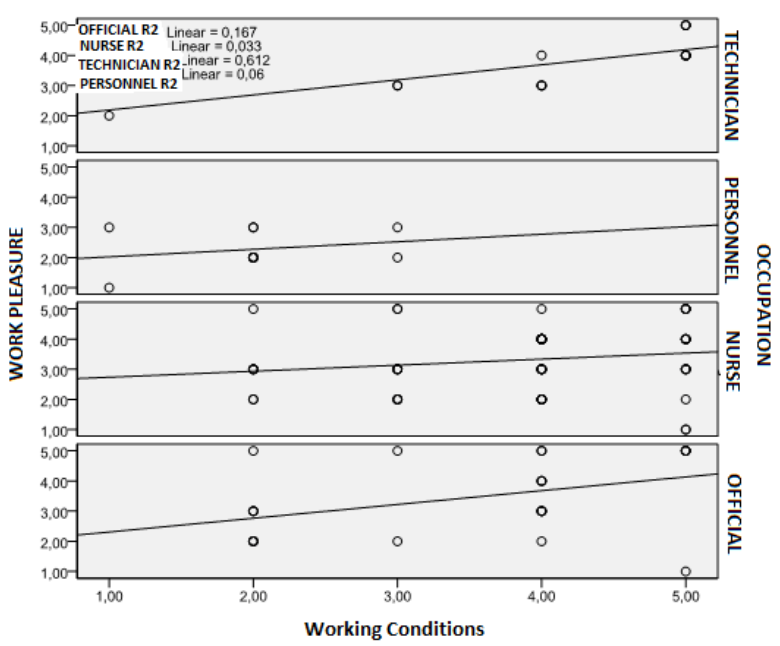

Figure 3. Pleasure of work and working conditions in occupational groups 
Discussion

Many studies based on area to determine the prevelance of headache was made via different data collection methods. There are big differences between prevelance results received from these studies. Results of some previous migraine prevalence studies changes between $1.3 \%$ and $33 \%$. This kind of difference probably depends on using different methods and choosing different groups (for instance;different socioeconomic conditions amongst cases, different diagnostic criterias, different standardization of headaches). All prevelance studies and clinical knowledge show that migraine is more frequent in females (male-female ratio 1:2-3). This difference possibly results from the hormonal differences between female and male. Migraine is likely to occur in the 2 nd and 3 rd decades. With the age rising, the prevelance drops (8-12).

In the sociodemographic study that Aygul et al. made using the migraine cases around Erzurum and neighbourhood they found 1.5 male to female ratio in 120 cases. Twenty three cases $(19.2 \%$ of all cases), whose average age was $32.2 \pm 10.7$, had migraine with aura whereas, 97 (80.8\%) had migraine without aura. 19 females (19\%) had aura while 81 (81\%) did not have aura; 4 males (20\%) had aura, but 16 males (80\%) did not have aura. It is important to state that high migraine prevelance after menarch in females is related to the triggering effect of estrogen and progesterone hormones (9-13).

As seen in all prevelance studies, female predominance is seen in our study (female/male ratio $=144 / 57=2 \cdot 5$ ). High female to male ratio is shown in other clinical or rural based studies in our country as well. This high ratio is explained females to consult a physician more frequently with the complaint of headache. Females having more susceptibility to headaches or giving extra response are other opinions about the difference (8-13). When the onset age is taken into consideration average onset age was fo und $23.12 \pm 9.5$ in males; $21.8 \pm 10.4$ in females $23 \pm 9.4$

The onset age of headache was $22.2 \pm 10.8$ years in males, $25.3 \pm 11.9$ years in females $(p>0.05)$, the duration of headache was $6.4 \pm 8.0$ hours in males, $7.9 \pm 10.3$ hours in females ( $p>0.05)$ and the duration of painkiller usage was $11.1 \pm 9.5$ years in males whereas it was $7.9 \pm 8.5$ years in females $(p=0.04)$ (Table 1).

In study by Aygul et al. the cases were mostly (\%80) from city center. Rural / urban area ratio was $1 / 4$. Almost half of the cases (46.7\%) had 11 years or more education. Most of the cases were married $(70.8 \%)$ and housewives were the majority in this group (49.2\%). $80 \%$ of the cases had mid or low level of income. Half of the cases were housewives. The reason for this is the females usually being housewives in the region. Unlike the old beliefs recent studies show that migraine prevelance has reverse relation with monthly income $(6,13,14)$. In the study that Stewart et al. have done it has shown that migraine prevelance and low monthly income had a strong correlation (6). It was stated that especially, females aged between 30-49 and with low income level were at high risk. Martin et al. suggested that migraine properties were similar both in females and in people live in rural area (13). Similar ratios are found in clinically based studies in our country and in an area based study migraine was found to occur statistically more frequent in married,graduated women who live in urban area $(9,15,16,17)$.

Seventy five persent of migraine headaches happen without any aura. In several studies it is stated that $1 / 3$ of cases had auras before the headache. The most common one is visual aura and sensory,aphasic,motor auras come later respectively. These auras rarely occur as an isolated symptom. 99\% accompany visual aura $(15,16,18)$. Basilary migraine is a subtype of migraine that includes at least 2 aura symp- 
toms resembling stem and occipital lobes (19). Aygul et al. revealed that the most common aura was visual (68\%), visual-sensory (24\%), pure sensory and visual-vertijenöz aura come later.

Headaches were mostly pulsating type in our study (32 people, $33.0 \%$ ) and pain mostly accompanied by sound intolerance (61 people, $62.9 \%$ ), physical activity (37 people, 38.1\%), light intolerance (34 people, 35.1\%). Cases stated that they used medicines without a doctor's advice (53 people, $54.6 \%, \mathrm{p}<0.0001$ ) and the method relieved the pain (57 people, $58.8 \%, p<0.0001)$. Most commonly used medicines were NSAIDs alone (25 people, $25.8 \%$ ) or paracetamol (20 people, $20.6 \%$ ) yet many of the cases used combinations of these drugs. It was nice to see that there was not drug abuse amongst the cases. Drinking herbal tea,resting and sleeping were the most common natural methods that were used by the cases. When the accompanying factors questioned, sound intolerance was the most common one and nausea-vomitting was secondary.

Questioning the methods that cases used against headache revealed that workers did not usually take doctor's advice even though they worked in an hospital. Especially the nurses used painkillers, since they could easily communicate with the doctors face to face. Lowly educated personnel group used drugs least like the technician group. It was common issue to use multiple methods to handle with headache in all groups (Figure 1).

Pathologies are affected by the interactions and adverse effects of drugs in multiple drug use. Multiple drug interactions ratios rise with the used drug count; the ratio is $13 \%$ in 2 drugs use, $38 \%$ in 4 drugs use, $82 \%$ in 7 or more drugs (20). Drugs need to be reviewed in every meeting. Drugs herbal drugs should be questioned. It is a suggested method that bringing whole of the drugs that the patient use (21). The drugs that is not indicated should be stopped. Treatment regimen should be simple and the drug count should be low as far as possible
(22). When compared to world's common principle, it is seen that the painkillers are the 2 nd most used drugs in our country (12\%) while they are not in top 5 drugs in the world. The problems about this topic are as follows: unnecessary and wrong prescription, inadequeate patient education and informing and related drug waste, pharmaceutists encouraging drug usage due to the stock excess, selling unprescribed drugs, not enough wise drug usage education or problems in practice (23).

In conclusion, headache onset age is early 2 nd decade in both males and females. MIDAS scores were average and not different but the majority of cases were females, high school or highly educated people and married people. It is concluded that cases mostly don't take doctor's advice before using painkillers and it is essential to educate doctors and patients about rational drug use.

\section{References}

1. Raj PP. Ağrı taksonomisi. In: Erdine S. (ed). Ağrı. 1. Baskı. İstanbul, Nobel kitabevi; 2002: 12-9.

2. Headache Classification Committee of the International Headache Society. Classification and diagnostic criteria for headache disorders, cranial neuralgias and facial pain. Cephalalgia 1998; 8 (suppl 7): 1-96.

3. Kayhan Z. Ağrı Klinik Anestezi; İstanbul, Nobel Kitabevi; 2004: 922-54.

4. Siva A. Baş Ağrısı Epidemiyolojisi Baş, Boyun, Bel Ağrıları Sempozyum Dizisi. Cerrahpaşa Tıp Fakültesi Sürekli Tıp Ĕgitimi Etkinlikleri 2002; 30: 9-14.

5. Aslantaş D, Metintaş S, Ünsal A, Kalyoncu C. Eskişehir Kırsal Kesim Öğrencilerinde Baş Ağrısı Sıklığı ve Etkileyen Etmenler. STED 2007; 16: 1-6.

6. Stewart WF, Lipton RB, Celantano DD, Reed ML. Prevalence of migraine headache in the United States: Relation to age, income, race and other sociodemographic factors. JAMA 1992; 267: 64־70.

7. De Lissovoy G, Lazarus SS. The economic cost of migraine; present state of knowledge. Neurology 1994; 44 (suppl 4): 556-62.

8. Türk Başağrısı Epidemiyoloji Çalışma Grubu. Headache Screening Survey. İstanbul; Piar-Gallup, Marketing Research Co, 1997; 1-53.

9. Aygül R, Deniz O, Güzelcik M, Aslan Ş. Migrenli Hastaların Sosyodemografik Profili. MJAU 2001; 33: 91-6.

10. Mavioğlu $H$, Karaca $S$, Yılmaz $H$, Korkmaz $H$, Artuğ R, Selçuki D: Başağrısı Poliklinik Hastalarının Demografik ve Klinik Profili. Düşünen Adam 2000; 2: 110-15.

11. Lüleci A. Maltepe İlçesi Doğurganlık Çağındaki Kadınlarda Migren Prevalansının Araştırılması. Dr Lütfi Kırdar Kartal Eğitim Ve Araştırma Hastanesi Nöroloji Kliniği. Uzmanlık Tezi. Yöneticisi: Türk Börü Ü, İstanbul, 2004. 
12. Çakmak G, Yayla V, Muhan A, Gülersönmez M, Apak i: Migrenli Hastalarda Sosyodemografik Değerlendirme. Beyin Damar Hastalıkları Dergisi 1996; 2: 29-31.

13. Martin BC, Dorfman JH, McMillan CA. Prevalence of migraine headache and association with sex, age, race, and rural/urban residence: a population-based study of Georgia Medicaid recipients. Clin Ther 1994; 16: 854-72.

14. Lipton RB, Stewart WF, Diamond S, Diamond ML, Reed $M$. Prevalence and burden of migraine in the United States: data from the American Migraine Study II. Headache 2001; 41: 646-57.

15. Mathew NT. Migraine. In: Evans RW, Mathew NT, eds. Handbook of Headache. Philadelphia: Lippincott Williams \& Wilkins, 2000: 2260.

16. Russell MB, Fenger $K$, Olesen J. The family history of migraine. Direct versus indirect information. Cephalalgia 1991; 11: 156-60.

17. Bener A, Uduman SA, Qassimi EM, Khalaily G, Sztriha L, Kilpelainen $\mathrm{H}$, Obineche $\mathrm{E}$. Genetic and Environmental factors associated with migraine in schoolchildren. Headache 2000; 40: 152-7.

18. Smetana GW. The Diagnostik Value Of Historical Features in Primary Headache Syndromes A Comprehensive Review. Arch Intern Med 2000; 160: 2729-2737.

19. Ferrari MD. Migraine. The Lancet 1998; 351: 1043-51.

20. Gallagher P. Inappropriate prescribing in the elderly. Journal of Clinical Pharmacy and Therapeutics 2007; 32: 113-21.

21. Fulton MM, Allen ER. Polypharmacy in the elderly: a literature review. J Am Acad Nurse Pract 2005; 17: 123-32.

22. Yarış F, Dikici MF. Yaşılıarda ilaç kullanımı: düşük dozda başlayalım, yavaş yavaş artıralım. Aile Hekimliği Dergisi 2008; 2(2) http://www.ailehekimligidergisi.org/

23. Dikici S, Baltacı D, Yılmaz A, Sayı S, Kara IH. Determination of headache features and related possible effective factors in adults admitted to Primary health-care center. Dicle Medical Journal 2012; 39: 35-41. 